\title{
Die verhouding Bybelse teologie en dogmatiese teologie
}

\author{
GMM Pelser
}

\begin{abstract}
The interrelationship between biblical theology and dogmatic theology The question posed in this article is whether biblical theology has the task of providing dogmatic theology with material for the latter to accomplish its own task. The answer given is that dogmatic theology should not be performed without first acknowledging the results of biblical theology. Although biblical theology is primarily concerned with what the text meant, it can and should also indicate what it means today. In this regard it can provide dogmatic theology with the necessary material, however in many cases perhaps in diverse and not in systematised form. To systematise where possible, is for dogmatic theology to decide.
\end{abstract}

Wanneer daar gevra word na die verhouding tussen twee sake soos hierbo genoem, is dit vanselfsprekend dat daar uit die staanspoor minstens redelike eenstemmigheid moet wees oor wat ons onder die aard en die omvang van die onderskeie groothede verstaan. ' $n$ Vergelyking tussen die twee het immers geen sin as ons nie weet wat ons met mekaar vergelyk nie. Met ons vraag na bogenoemde verhouding het ons reeds minstens geïmpliseer dat hulle van mekaar te onderskei is en dat ons op grond van hierdie feit moet vra of hulle wel nog met mekaar in verband staan, of dalk glad nie. In die besinning hieronder sal nie gepoog word om 'n definisie van dogmatiese teologie te gee nie; wat dit is, sal meer veronderstel as omskryf word. Daar sal egter wel gevra moet word na wat Bybelse teologie is om van daaruit te oorweeg wat sy verhouding met dogmatiese teologie moet wees.

\section{WAT IS BYBELSE TEOLOGIE?}

Wanneer 'n mens die geskiedenis van Bybelse teologie nagaan en kennis neem van hoe dit in die laaste paar dekades bedryf is, word dit gou duidelik dat die begrip Bybelse teologie nie so vanselfsprekend en eenduidig is as wat dit op die oog af lyk nie. Die vraag wat eerste voor ' $n$ mens opdoem en ook in die geskiedenis van Bybelse teologie dikwels in die brandpunt was, is of Bybelse teologie slegs ' $n$ beskrywing is 
van die teologie in (van) die Bybel of 'n teologie gegrond op die Bybel. Is hy eersgenoemde dan is hy ' $n$ wetenskap wat suiwer histories-deskriptief weergee wat die Bybel 'teologies' te sê gehad het (what it meant), en daarmee is sy taak afgehandel. Is hy laasgenoemde dan is hy 'n wetenskap wat Bybelse uitsprake interpreteer met die vraag na hulle betekenis vir die hede (what it means) en hulle dus relevant vir die hede maak. In hierdie geval word Bybelse uitsprake dan ook nie bloot herhaal nie, maar in elke nuwe tyd en situasie geaktualiseer.

Hierby is daar egter ook ' $n$ ander belangrike vraag en dit is of Bybelse teologie ' $n$ teologie in die engere of in die breëre sin is. Verstaan ons naamlik onder teologie letterlik elke uitspraak oor God en elke uitspraak met religieuse strekking of verstaan ons daaronder in engere sin slegs uitsprake wat in direkte verband staan met die God-mensverhouding? Boers (1979: 13) stel die volgende voor as 'n 'working definition' van teologie: 'n Koherente, logiese, noodsaaklike sisteem van algemene idees in terme waarvan elke element van ons ervaring in verband met sake wat met God in verband staan, geïnterpreteer kan word. Hierdie definisie beskou hy as eng, terwyl hy die adjektief teologies in ' $n$ meer algemene sin gebruik.

Dit is natuurlik nie maklik om uit te maak wat alles prinsipieel onder hierdie begrip tuisgebring mag word en wat nie. Terwyl 'n mens dikwels die gewaarwording het dat daar oor die algemeen betreklik breed gedink word rondom die begrip Bybelse teologie, blyk dit dat die saak in verreweg die meeste gevalle waar persone ' $n$ teologie van die Nuwe Testament probeer skryf het, anders daar uitsien. Hoewel al hierdie pogings oorkoepelend die titel 'Teologie' dra, word daarin nie al die materiaal van die Nuwe Testament as teologie beskou of behandel nie. So behandel Bultmann slegs die Paulusbriewe (7) en die Johannesevangelie en -briewe as teologie, Kümmel slegs die Paulusbriewe (9) en Lohse die Sinoptiese Evangelies, Paulusbriewe (7) en die Johannesevangelie en -briewe. Maar selfs in hierdie geval waar slegs sekere korpusse in die Nuwe Testament as teologie beskou en hanteer word, bly die vraag nog of alles van hierdie korpusse as teologie beskou kan word. Dit lyk onvermydelik dat selfs in so 'n geval nie elke uitspraak eenvoudig as teologie beskou sal kan word nie.

Op die vraag wat Bybelse teologie is, is die antwoord nie maklik nie en daar sal seker altyd meningsverskil wees. Boers se definisie lyk na'n bruikbare definisie, behalwe dat mens ' $n$ vraagteken moet plaas oor sy tipering van teologie as ' $n$ 'koherente logiese noodsaaklike sisteem van idees'. Hieroor later meer. 
Maar afgesien van die probleem in verband met die aard en die omvang van die begrip Bybelse teologie is daar ook ander fasette van die saak wat as probleemvrae rondom die begrip sentreer. Sedert die Reformasie het daar, soos bekend, so 'n ontwikkeling plaasgevind in Skrifbeskouing en -gebruik, metodes van eksegese en die daarmee gepaardgaande Bybelse teologie dat daar vandag eenvoudig nie meer ongekompliseerd met die saak omgegaan kan word nie. Problematies het geword sake soos die kanon, die eenheid en verhouding Ou en Nuwe Testament, die eenheid van die onderskeie testamente self, die verhouding godsdiens en teologie, die relevansie of historiese kontingensie van Bybelse materiaal, ensovoorts. Hieraan moet ons nou kortliks aandag gee.

\section{PROBLEEMVRAE WAARMEE DIE BYBELSE TEOLOGIE TE KAMPE HET}

\subsection{Die kanon}

Dit lyk vanselfsprekend dat wanneer dit om 'Bybelse' teologie gaan, die kanon, soos ons hom voor ons het, as bron vir ons teologiese besinning moet dien. As só vanselfsprekend word die saak egter lank nie meer beskou nie. Daar is nie alleen die vraag na die oopheid van die kanon na buite nie, maar ook na binne. Na buite raak dit die vraag of buiteBybelse literatuur soos die literatuur van die inter-testamentêre periode en die vroeg-Christelike literatuur nie ook in berekening gebring moet word nie. Veral as gevolg van die werk van die godsdienshistoriese skool het die vraag ontstaan of daar teologies sinvol oor Bybelse konsepte nagedink kan word sonder kennisname van die breëre godsdienstige konteks, wat ook nie-Bybelse godsdienstige strominge insluit. Selfs al sou so ' $n$ breë konteks nie as aanvaarbaar beskou word nie, bly die vraag nog of daar nie bepaalde geskrifte is wat net soveel reg op insluiting in die kanon sou hê as ander wat aanvanklik omstrede was en eers na ' $n$ betreklik lang tydsverloop finaal in die kanon opgeneem is nie. Die vraag is dus of die kriteria wat tydens kanonvorming gegeld het, vandag nog as deurslaggewend beskou kan word, byvoorbeeld die kriterium van apostoliese outeurskap.

Al word die kanon de facto as geslote en afgesluit beskou, is daar nog steeds die vraag of dit nie na binne as in ' $n$ sekere sin oop beskou moet word nie. Die moeisame proses van kanonvorming laat ' $n$ mens reeds wonder en dit is bekend hoe Luther volgens die maatstaf van Christum treiben oor sekere Nuwe-Testamentiese geskrifte geoordeel het. Voeg 
hierby Semler (1725-1791) wat as die vader van histories-kritiese teologie beskou word, se oortuiging dat daar onderskei moet word tussen die Woord van God in die Skrif en die woorde van die Skrif self. Dit beteken vir hom dat nie alle dele van die Skrif as geïnspireerd beskou mag word nie en dat hulle derhalwe nie oor gelyke kanoniese of normatiewe gesag beskik nie. Hierdie kwessie van die oopheid na binne raak dus nie alleen bepaalde geskrifte nie, maar ook gedeeltes in 'n geskrif.

Streng gesproke behoort die Bybelse teoloog met die kanon as de facto geslote korpus te werk. Hy sal egter nie sy oë daarvoor kan sluit dat nie alle dele van die kanon teologies dieselfde aanspraak maak nie. Hoewel die gedagte van 'n kanon in die kanon gewoonlik hewige reaksie uitlok, is dit nie te ontken nie dat daar tradisioneel so met die kanon te werk gegaan is en nou nog te werk gegaan word. Baie hang natuurlik af van die tydsgees en die situasie waarin die teologie hom op ' $n$ bepaalde tyd bevind. Dit beteken nie dat sekere geskrifte fisies uit die kanon verwyder moet word nie. Feit is net dat hulle nie almal altyd dieselfde aandag kry of dieselfde gewig dra nie. Tog kan nie ontken word dat daar ' $n$ sentrum en 'n periferie is nie, sonder dat daarmee noodwendig die oordeel meer kanoniek - minder kanoniek gefel word.

\subsection{Die verhouding Ou en Nuwe Testament}

Die kritiese omgaan met die Bybel sedert die Aufklärung het ook die verhouding tussen $\mathrm{Ou}$ en Nuwe Testament problematies gemaak. Daar is ingesien dat ons hier met twee groothede te doen het wat nie op dieselfde vlak lê nie en volgens sommige (bv Hirsch) in 'n permanente antitetiese spanning met mekaar verkeer. Sedert Bauer (1755-1806) teen die einde van die agtiende eeu Ou en Nuwe Testament Teologie finaal geskei het, nadat Richard Simon (1635-1712) die eerste stap in die rigting gegee het, bestaan daar nie meer so iets as 'n gesamentlike Bybelse teologie van albei die testamente nie. Dit het vanselfsprekend belangrike implikasies vir Bybelse teologie omdat dit dan nie meer kan bestaan uit ' $n$ ordening van materiaal wat vryelik uit albei die testamente verkry is nie. Hierdie ontwikkeling het natuurlik die vraag na die verhouding tussen die testamente akuut gemaak en tot vandag toe steeds brandend gehou. Verskeie antwoorde is aangebied waarmee ò vir algehele diskontinuïteit òf vir kontinuïteit besluit is, ò na ' $n$ middeweg gesoek is met die aanvaarding van gedeeltelike diskontinuïteit, 
maar tog ook 'n bepaalde kontinuiteit. In die gevalle waar op diskontinuïteit besluit is, vind ons enersyds ' $n$ onderwaardering van die $\mathrm{Ou}$ Testament (bv Von Harnack, Delitzsch, Bultmann, e a) en andersyds ' $n$ onderwaardering van die Nuwe Testament (bv Van Ruler, Miskotte, e a). By die pogings om eenheid en kontinuiteit te bewys, figureer as patrone van kontinuiteit gewoonlik sake soos historiese verbondenheid, skriftuurlike afhanklikheid, gemeenskaplike woordgebruik, gemeenskaplike temas, tipologie, die belofte-vervullingskema, heilsgeskiedenis en eenheid in perspektief (vgl Hasel 1978: 184-186). Nie een van hierdie patrone is egter sonder sy vrae en probleme nie en die meeste hiervan berus op 'n terugwaartse blik vanuit die Nuwe Testament.

Dat die Bybelse teoloog hom hier voor 'n gewigtige vraagstuk bevind, is nie te ontken nie. Tot dusver is daar ook nog nie ' $n$ bevredigende antwoord op die probleem gevind nie. Wat egter gebiedend is, is dat elke testament eers toegelaat moet word om volledig en selfstandig aan die woord te kom alvorens daar na die kontinuiteit, indien enige, gevra kan word. Die feitelike situasie is natuurlik dat die werk op hierdie onderskeie terreine van die Bybelwetenskap so gespesialiseerd en omvangryk geraak het, dat een individu eenvoudig nie meer albei kan probeer beheers en van daaruit sinvol oor eenheid en kontinuïteit kan besluit nie.

\subsection{Die verskeidenheid binne die twee testamente self}

Nie alleen die eenheid tussen die twee testamente het as gevolg van die kritiese wetenskapsbeoefening problematies geword nie, dit het ook die geval geword met die testamente self. Daar heers vandag onder Bybelwetenskaplikes algemene instemming dat die Bybel nie alleen saamgestel is uit verskillende literêre soorte wat elkeen volgens sy eie konvensies geïnterpreteer moet word nie, maar ook uit verskillende korpusse wat elkeen sy eie siening of verstaan van die God-mensverhouding of Bybelse gebeure daarop nahou. Hiervolgens het ons dan, indien die Bybel wel teologie bevat, nie in die Bybel te doen met 'n teologie in die enkelvoud nie, maar met 'n meervoud van teologieë wat in baie gevalle nie harmoniseerbaar is nie en in sommige gevalle selfs teenstrydig is. Hoewel van hierdie teologieë langs mekaar kan staan en pogings aangewend is om ander te harmoniseer, geslaagd of nie, neem dit nog nie weg dat ons met 'n verskeidenheid te doen het nie. Hierdie verskeidenheid bestaan ook nie alleen tussen die verskillende korpusse nie, dit bestaan in sekere gevalle ook binne die kor- 
pusse. So blyk dit byvoorbeeld dat nie alle begrippe oral deur Paulus eenduidig gebruik word nie.

Hiermee word natuurlik nie ontken dat daar wel ' $n$ bepaalde eenheid in die testamente of dele daarvan aanwesig is nie. Feit is net dat die Bybelse teoloog nie sy oë vir die verskeidenheid mag sluit nie; dit is eenvoudig daar. Dit is dan ook opmerklik dat in die meeste teologieë van die Nuwe Testament wat gedurende die afgelope paar dekades verskyn het, die verskillende korpusse afsonderlik behandel is (bv Bultmann, Conzelmann, Lohse, Kümmel, Goppelt) in stede daarvan dat meerdere korpusse gesamentlik rondom bepaalde temas aan die woord gestel is (bv Stauffer, Richardson).

Dit lyk in die lig hiervan onvermydelik dat die Bybelse teoloog eers die verskeidenheid behoorlik sal moet verdiskonteer alvorens hy probeer beweeg na 'n moontlike samehang of eenheid. Maar wat staan hom te doen met die onharmoniseerbares of teenstrydiges? Hy sal nie sommer oorhaastig kan kies nie, maar as hy moet kies, sal die kriterium gewis ook nie volgens persoonlike voorkeur of vooroordeel gevind mag word nie. Hy sal subjektiwiteit nooit volkome kan uitskakel nie, maar hy sal moet besef dat die werklike kriterium agter die tekste lê; wat die Nuwe Testament betref, beslis by Jesus Christus, al word daarin ook so meervoudig oor Hom getuig.

\subsection{Die vraag of die Bybel teologie bevat}

By hierdie vraag herinner ons ons die ander opinie van Semler, naamlik dat ons in die Skrif moet onderskei tussen godsdiens (Religion) en teologie, 'n onderskeiding waarby veral Wrede (1859-1906) hom sterk aangesluit het. Godsdiens word dan gesien as die blywende, teenoor teologie as die plaaslike en tydelike. Volgens Semler het die Bybelse tekste 'n boodskap vir hulle eie tyd gehad sonder die intensie om iets vir latere tye te sê en na Wrede se oortuiging het nòg die godsdiens in die Bybel nòg die teologie die bedoeling om vir vandag normatief te wees of te dien as morele opbou van die kerk. Om hierdie rede moet Bybelse teologie dit nie as sy taak sien om in die Bybel te vra na die normatiewe of opbouende nie, maar slegs histories vra na wat geglo, gedink, geleer, gehoop, ensovoorts is; dus nie na die inhoud van die tekste nie, maar na die geskiedenis van die godsdiens en teologie van die vroegste kerk. In die ware sin van die woord kan daar dan ook nie van teologie gepraat word nie, behalwe in ' $n$ mate in die geval van Paulus. Paulus se teologie was egter godsdiens en sy godsdiens teologie. 
Hierdie standpunt wat basies ook die standpunt van die godsdienshistoriese skool is, verteenwoordig natuurlik 'n uiterste en het nie algemene aanvaarding gevind nie. So byvoorbeeld nie by Schlatter nie, wat die standpunt gehuldig het dat die Bybel, en bepaald die Nuwe Testament, nie neutraliteit toelaat nie, maar 'n reaksie of antr"nn-f van sy lesers en daarom ook van die teoloog verwag. Schlatter het nie ontken dat die Bybel godsdiens bevat nie, maar in elk geval meer teologie as godsdiens. Ook Bultmann was oortuig daarvan dat die Nuwe Testament wel iets vir die leser te sê het en dat die saak waarom dit in die teks gaan, die leser tot selfverstaan, tot Existenzverständnis kan bring. Om hierdie rede moet daar deur middel van Sachkritik nie alleen gevra word na die saak waarom dit gaan nie, maar ook na die wyse waarop daaraan uitdrukking gegee is. Dit is hierdie saak wat vir vandag relevant en van belang is.

Dat die Bybel data bevat oor hoe daar geglo, gehoop en geleer is, hoef nie oor verskil te word nie. Dat daar egter in die Bybel ook teologiese refleksie aanwesig is, sal kwalik ontken kan word, hoewel dit te betwyfel is of ons daaronder teologie in die streng sin van die woord kan verstaan. Ebeling (1967: 86) stel die saak soos volg: 'Obwohl die Bibel überwiegend nicht Theologie in strengen sinne enthält, drängt sie doch hin auf theologische Explication.' En Barr (1973: 90): 'We can certainly agree that some elements within the Bible can be well characterized as "religion" rather than as "theology"; but this can hardly be carried to the point of denying the existence of theology within the Bible ... A distinction has to be made however between overt theological statement and implied or underlying theology' (vgl egter Boers 1982: 10). Dat hierdie teologiese refleksie vir daardie tyd en vir die lesers vir wie dit bedoel was, normatiewe karakter gehad het, moet as ' $n$ feit aanvaar word. Mag egter sonder meer aanvaar word dat wat normatief vir 'n tyd en situasie in die verlede was, ook normatief vir later tye is? Daar kan nie ontken word dat die Bybel materiaal bevat wat vandag as kontingent beskou moet word nie. Vir die Bybelse situasies was dit natuurlik normatief en nie kontingent nie. Dit het in nuwe situasies kontingent geword. Maar wat moet as kontingent beskou word en wat nie? Dat minstens bepaalde Bybelse stof wel vir vandag as relevant beskou word, berus natuurlik op die a-prioriese aanvaarding van die Bybel as gesaghebbende Woord van God. Vir die Bybelse teoloog staan dit buite diskussie. Die besluit oor wat kontingent en wat teologies relevant is, is egter nie so eenvoudig nie. Terwyl dit in bepaalde gevalle betreklik maklik behoort te wees, sal dit in ander nie so voor-die-hand-liggend 
wees nie. Verskeie faktore sal altyd hier 'n rol speel waarvan die vooronderstellings van die teoloog en die situasie waarin die tekste hulle aktualisering moet vind, nie die geringste is nie. Dit beteken dat elke individuele teoloog en elke nuwe situasie medebepalend is vir wat as relevant beskou sal word.

\section{DIE VERHOUDING BYBELSE TEOLOGIE EN DOGMATIESE TEOLOGIE}

Dit bring ons by ons eintlike vraag na die verhouding tussen Bybelse teologie en dogmatiese teologie. Of om dit nader te presiseer, die vraag of Bybelse teologie ' $n$ bepaalde diens te lewer het vir dogmatiese teologie en of dogmatiese teologie op hierdie bydrae aangewys is om sy werk te kan doen. Wanneer oor hierdie vraag nagedink word, word daar in verskeie kringe positief geoordeel oor die bydrae wat Gabler (1753-1826) in hierdie verband gelewer het. Gabler word beskou as die eerste persoon wat Bybelse teologie as 'n afsonderlike selfstandige wetenskap onafhanklik van dogmatiese teologie gevestig het. Dit het hy gedoen deur middel van sy professorale intreerede op 31 Maart 1787 en uit reaksie teen wat tot op daardie stadium wel al as Bybelse teologie bekend gestaan het, maar in wese niks anders was as dicta probantia vir die dogmatiek nie. Gabler was van oortuiging dat die Bybel die enigste basis vir alle teologie moet wees, met 'n Bybels gefundeerde dogmatiese teologie as die kroon daarop. Die daarstelling van 'n Bybelse teologie was vir hom nie die doel op sigself nie, maar deel van 'n groter onderneming ten behoewe van teologie as geheel. Die Bybel bevat volgens Gabler nie teologie nie, maar godsdiens. Godsdiens en teologie staan teenoor mekaar, hoewel teologie gebaseer is op godsdiens. Die taak van Bybelse teologie is om ' $n$ bemiddelende funksie tussen die Bybelse godsdiens en dogmatiese teologie te vervul, waarvoor dit uiters geskik is, aangesien dit in albei deel. Dit moet die Bybelse godsdiens transformeer tot ' $n$ teologiese sisteem wat die basis kan vorm vir dogmatiese teologie. Vir hierdie doel het Gabler onderskei tussen Bybelse teologie in ' $n$ breër sin en Bybelse teologie in ' $n$ enger sin, deur hom ook onderskeidelik beskryf as waar en suiwer. Bybelse teologie as ware teologie is die sistematiese beskrywing van die Bybelse godsdiens waarin gelyke aandag gegee word aan alle konsepte, ook die kontingente. Bybelse teologie as suiwer teologie is die sistematiese beskrywing van die onveranderlike konsepte, uitgesluit die kontingente, met die doel om dit as basis vir dogmatiese teologie aan te bied. 
Hiermee wou Gabler vir dogmatiese teologie 'n vaste basis bied waaroor dan dogmaties gefilosofeer kon word. Dit is wel so dat dogmatiese teologie kontingent is deurdat dit voortdurend verander, afhangende van die vermoë van die teoloog, die tyd, die plek, die denominasie, ensovoorts, maar dit moet gebaseer wees op die onveranderlike vaste basis van die godsdiens om nie totaal kontingent te word nie. Hierteenoor is Bybelse teologie stabiel omdat dit gebaseer is op die onveranderlike Bybelse godsdiens.

Die vraag is nou of die Bybelse teoloog hom met die standpunt van Gabler oor die doel en die taak van Bybelse teologie met betrekking tot dogmatiese teologie kan vereenselwig. Die antwoord op die vraag hang in ' $\mathrm{n}$ groot mate af van die konteks waarin Bybelse teologie beoefen word, naamlik of dit in ' $n$ kerklike konteks en in diens van die kerk is of nie. Dit lyk onvermydelik dat indien dit in ' $n$ kerklike konteks beoefen word, Bybelse teologie en dogmatiese teologie minstens nie in 'n konkurrente verhouding tot mekaar moet staan nie. 'n Mens sou ook kon vra of Bybelse teologie in konkurrensie met dogmatiese teologie nog Bybelse teologie genoem kan word. Indien die resultate van Bybelse teologie nie afgestem is op die verkondiging nie, sou dit waarskynlik nie meer kon wees as 'n antwoord op die vraag what it meant nie. Dit lyk egter vanselfsprekend dat daar in kerklike konteks nie hierby stilgestaan mag word nie, maar dat ook gevra sal moet word na what it means. ' $n$ Kerklike teoloog sal die Bybelse tekste eenvoudig nie neutraal kan lees nie. Die doelwit van sy werk is immers om die teks vir die verkondiging van die kerk hier en nou en in elke nuwe situasie vrugbaar te maak.

Met die uitgangspunt dat Bybelse teologie en dogmatiese teologie nie konkurrente van mekaar moet wees nie, is die vraag of eersgenoemde ' $n$ bydrae vir laasgenoemde kan en behoort te lewer, natuurlik nog nie beantwoord nie. In die lig van die feit dat Bybelse teologie veronderstel is om direk op die teks gegrond te wees, lyk dit voor-diehand-liggend dat hy ' $n$ bydrae sal kan en moet lewer vir dogmatiese teologie wat verder van die teks af staan, maar ook veronderstel is om op die teks gegrond te wees. Dit is egter' $n$ vraag of Bybelse teologie sy werk moet doen met die oog daarop om dogmatiese teologie van 'n soort bloudruk te voorsien, hoe prysenswaardig Gabler se intensie ook al geag mag word. Hy kan so maklik die gevaar loop om 'n Bybelsdogmatiese in plaas van 'n Bybelse teologie te word. Dit beteken natuurlik nie dat Bybelse teologie nie graag sou wou sien dat dogmatiese teologie van sy resultate kennis neem en daarvan gebruik maak nie. Hy 
mag hom net nie in 'n situasie bevind waarin sy aandag tussen die teks aan die een en dogmatiese teologie aan die ander kant verdeel is nie.

Daar sal steeds onthou moet word dat Bybelse teologie en dogmatiese teologie, al deel hulle ook in die grond van die saak een basis, na aard en doel van mekaar verskil. Dogmatiese teologie sistematiseer nie alleen baie sterker as Bybelse teologie nie, maar neem die teologiese saak ook verder as wat Bybelse teologie homself kan veroorloof. Eersgenoemde is sterk normatief ingestel en laasgenoemde nie. Omdat dogmatiese teologie hom in 'n sekere sin van die teks distansieer 'filosofeer' hy oor die teks op 'n wyse wat Bybelse teologie nie kan doen nie. Dogmatiese teologie kan by geleentheid ook aan geen bepaalde teks gebonde wees nie en hom bedien van konsepte en begrippe wat nie in die teks aanwesig is nie. Dit kan selfs 'n dogmatiek wees gebaseer op dogmatiek. Dit het dus baie meer beweegruimte en is baie vryer as Bybelse teologie.

Dit is onvermydelik dat Bybelse teologie en dogmatiese teologie in spanning met mekaar sal verkeer. Dit kan 'n ongesonde spanning wees, maar dit hoef nie, en in kerklike konteks behoort dit nie te wees nie. In werklikheid is hierdie spanning nie net onvermydelik nie maar ook nodig. Dit is onvermydelik omdat Bybelse teologie as hy sy eksegetiese werk behoorlik doen, dogmatiese teologie altyd voor sal wees met betrekking tot die verstaan van die teks waarop albei hulle beroep. Die spanning is egter nodig omdat dit die twee in 'n voortdurende gesprek met mekaar moet laat tree. In hierdie gesprek sal die twee dissiplines nie alleen die geleentheid hê om aan mekaar kritiese vrae te stel nie, maar ook om die resultate van hulle wetenskapsbeoefening aan mekaar voor te lê en die haalbaarheid daarvan te toets. In so 'n gesprek sal insette van albei kante ter bevordering van 'n gemeenskaplike saak gelewer kan word. Daar sal ook beter begrip vir mekaar se probleme kom en beter waardering vir mekaar se plek en funksie.

Bybelse teologie sal egter nie vir dogmatiese teologie meer kan aanbied as wat hy deur onbevange eksegese van die teks verstaan nie. $\mathrm{Hy}$ sal ook kan probeer aandui wat hy as relevant vir die hede beskou en wat nie. Hy sal nie, waar die teks hom nie daarvoor leen nie, 'n sisteem op die teks kan afdwing nie. Dogmatiese teologie sal moet aanvaar dat die tekste waarmee die Bybelse teologie werk, in die oorgrote meerderheid van gevalle onsistematies is. Aan die ander kant mag die Bybelse teoloog nie nalaat om waar sistematiese ordening moontlik is, dit wel te doen nie. Daar sal verder aanvaar moet word dat Bybelse teologie die verskeidenheid van teologieë van die tekste sal moet reflekteer sonder 
om noodwendig 'n keuse te maak, te probeer harmoniseer, 'n sentrum te probeer vind of die stof komprehensief aan te bied. Hy sal ook omdat hy met tekste werk wat tot op groot hoogte situatief is en nie bedoel is om algemeen geldende teologiese uitsprake in die moderne sin te wees nie, op hierdie feit moet wys en moet aantoon dat sulke tekste nie reglynig en simplisties tot algemeen geldende teologiese norme verhef mag word nie. Die Bybelse teoloog kan ongelukkig ook nie 'die teologie' van die Bybel aanbied nie. So min as wat ' $n$ finale dogmatiek moontlik is, so min bestaan daar ' $n$ finale teologie van die Bybel. Daar is alleen maar ' $n$ veelvoud van teologieë afhangende van wie daardie teologie geproduseer het en van die teologiese milieu waarbinne dit tot stand gekom het. Ons moet toegee dat die gevarieerdheid van Bybelse teologieë dikwels vir die dogmatikus na 'n verwarrende prentjie lyk. Die prentjie is egter nie heeltemal so donker as wat dit lyk nie. Die dogmatikus sal wel baie vind wat vir hom bruikbaar kan wees. Hy sal egter moet insien dat tekste vir meervoudige interpretasie vatbaar is en dat hy gevolglik nie in alle gevalle 'n eenstemmige antwoord kan verwag nie.

Om mee af te sluit. In die kerklike konteks kan dit nie anders nie, as dat Bybelse teologie en dogmatiese teologie, hoewel as selfstandige wetenskappe, gesamentlik en aanvullend tot mekaar ' $n$ taak het ten dienste van die geloof en die lewe in die geloof. In hierdie taakvervulling lewer Bybelse teologie aan dogmatiese teologie sy bydrae deur bemiddelend tussen die teks en dogmatiese teologie die teks vir dogmatiese teologie bruikbaar te transformeer. Op sy beurt lewer dogmatiese teologie sy bydrae deur die saak waarom dit in die teks gaan, sistematies te verwoord en verder te voer. Streng gesproke kan dogmatiese teologie nie sy werk doen sonder om kennis te neem van die resultate van Bybelse teologie nie. Hoewel die Bybelse teks in die grond van die saak die fondament is waarop die dogmatiek sy teologie bou, kan dit nie anders nie as dat die resultate van Bybelse teologie die pilare moet wees waarop hy sy struktuur oprig, die pilare wat reeds deur Bybelse teologie op die teks as fondament gevestig is. Hy bou dus indirek op die teks van die Bybel, maar direk op die resultate van Bybelse teologie. Let egter op dat die dogmatikus op die resultate van Bybelse teologie bou en nie soseer op dié van die Bybelse teoloog nie; die dogmatikus kan immers, indien moontlik, self as voorarbeid vir sy teologie, Bybelse teologie beoefen. 


\section{Literatuurverwysings}

BARR, J 1973. The Bible in the modern world. London: SCM.

BOERS, H 1979. What is New Testament theology? Philadelphia: Fortress.

BOERS, H 1982. The problem of Jews and gentiles in the macro-structure of Romans. Neotestamentica 15, 1-11.

EBELING, G 1967. Wort und Glaube. 3. Auflage. Tübingen: Mohr.

HASEL, G 1978. New Testament theology: Basic issues in the current debate. Grand Rapids: Eerdmans. 